\title{
Development of Ethanolic Extract of Pinang Masak Jambi (Areca Catechu L.) as A Modulator of Doxorubicin Cytotoxic Effect in Breast Cancer Therapy
}

\author{
Fitrianingsih, Indri Maharini, Diah Tri Utami* \\ Pharmacy Study Program, Faculty of Science and Technology, Universitas Jambi, Jambi, Indonesia
}

\begin{abstract}
ARTICLE HISTORY

Received: January 2019

Revised: March 2020

Accepted : April 2020

Doxorubicin is one of the chemotherapy agents that is often used in breast cancer therapy. Phenomenon of breast cancer cell resistance to chemotherapy agents has been traced to the molecular level. The development of compounds that can overcome drug resistance chemotherapy needs to be continuously developed, especially agents with specific molecular targets, namely P-glycoprotein (Pgp), NFkB, cyclin, and cyclin-dependent kinase (CDK). Another alternative is the combination of chemotherapy agents with chemopreventive agents (co-chemotherapy) to reduce side effects and increase sensitivity of cancer cells. Doxorubicin is often used in breast cancer therapy. This study was performed to determine the effect of ethanolic extract of Pinang Masak Jambi (Areca catechu L.) (EEPMJ) and doxorubicin combination on MCF-7 breast cancer cells. Cytotoxic assay of EEPMJ and doxorubicin, alone, or in combination, was done using MTT test method to determine the $\mathrm{IC}_{50}$ and $\mathrm{CI}$ (Combination Index) values. The results indicated that EEPMJ and doxorubicin had $\mathrm{IC}_{50}^{50}$ values of $75.1 \mu \mathrm{g} / \mathrm{ml}$ and $22 \mu \mathrm{g} / \mathrm{ml}$, respectively. Based on CI values, all combination concentration showed varying $\mathrm{CI}$ values. The concentration of $1 / 8 \mathrm{IC}_{50}$ of EEPMJ with $1 / 2,1 / 4$, and $1 / 8$ IC50 of doxorubicin showed a strong synergistic effect (CI $0.1-0.3$ ), with the inhibition of cell viability up to $67.39 \%$. This synergistic effect occurs because EEPMJ potentially could increases the cytotoxicity of doxorubicin.
\end{abstract}

*corresponding author

Email:diahtriutami@unja.ac.id
Keywords: doxorubicin; Areca catechu L; breast cancer; MCF-7

\section{INTRODUCTION}

Breast cancer is the second most common disease among women worldwide (InfoDATIN, 2016), with $12.9 \%$ of the occurrence caused death (Globocan, 2012). Globally, $80-85 \%$ of death occurs in low- and middle-economicincome countries. Based on the statistics of the American Cancer Society (2018), the incidence of breast cancer is increasing every year, with global cases is 268,670 . The World Health Organization (2008) stated that the worldwide estimation of new cases is expected to increase up to 7 times by 2030 in Indonesia. Moreover, The Jakarta Breast Cancer Foundation as a part of Dharmais hospital (2009), stated that breast cancer is the number second cause of death for women in Indonesia.

There are several ways to treat breast cancer, including surgery, radiation therapy, chemotherapy, and a combination of these therapies. Chemotherapy is one of the treatments that often used in cancer therapy. Still, chemotherapyalso often fails to cope with cancer treatment because of the low selectivity of these anticancer drugs. The low selectivity of chemotherapeutic agents causes some side effects even in the usual dosage. According to Poddar et al. (2009), side effects that occur include alopecia, nausea and vomiting, myelosuppression, hemorrhagic cystitis, mucositis, impaired renal function, cardiac toxicity, hypersensitivity reactions, electrolyte balance disorders, and venous thrombosis. Especially if there is an increase in dose and frequency of using the chemotherapy drugs so that they can cause increasingly serious side effects such as hepatotoxic, cardiotoxic and neurotoxic (Smeltzer \& Bare, 2002; Han et al., 2008; ElSayyad et al., 2009; Ramadori \& Cameron, 2010; Lee \& Westcarth, 2012).

Doxorubicin, often used in breast cancer therapy, is the first-line drug in the treatment of various types of cancer, but the effectiveness is limited due to the effects of cardiotoxicity when used in the long term (Han et al., 2008). Moreover, it is known to cause resistance because it can induce over-expression of P-glycoprotein (Pgp), which is causing the efflux of drugs from inside the cell (Li et al., 2016). Therefore, the decrease in expression and inhibition of Pgp is an essential strategy in the development of molecular-targeted agents to overcome the resistance of breast cancer cells.

An effort to increase the efficacy of therapy while reducing side effects due to increased drug dosages can be done through a combination therapy (co-chemotherapy). Co-chemotherapy is a cancer therapy strategy that combines a compound with other chemotherapy agents (Setiawati et al., 2011). Combining several drugs as well 
as with compounds from natural ingredients is possible and quite beneficial in cancer therapy. One of the natural ingredients that can be used to assist chemotherapy with doxorubicin is Pinang Masak Jambi (Areca catechu).

Pinang is a plant that has the potential to be developed into a chemopreventive agent. Pinang Masak Jambi currently used by the Jambi people as a beverage ingredient that has a cytotoxic effect and cell cycle modulation. Pinang contains phenolic and flavonoid compounds that potentially give antioxidant and anticancer activities on squamous carcinoma (HSC)-3, HSC-2, and human keratinocyte (HaCat) cancer cell line (Sari et al., 2017). Furthermore, proanthocyanidin content on Pinang has antibacterial, antiviral, anticarcinogenic, antiinflammatory, anti-allergic, and vasodilating effects. Previous study showed that flavonoid fractions (flavonol, anthocyanin, flavan-3-ol, and proanthocyanidin) from cranberry extract can inhibit cell growth through G1 and G2 / M cell cycle arrest and induce apoptosis in breast MDA-MB-435 cancer cells (Ferguson et al., 2004). Whereas, proanthocyanidins in grape seeds have cancer cell growth inhibitory activity through downregulation of Bcl-XL expression that leads to apoptotic cell death (Leigh, 2003). These allow the cytotoxic activity of proanthocyanidins in areca nut through the same mechanism. Based on this, it is necessary to conduct Pinang Masak Jambi research as an anticancer or combination agent to reduce the resistance with specific molecular targets.

\section{METHODS}

\section{Test Compound and Reagents}

Pinang Masak Jambi was taken from Selat Village, Pemayung Subdistrict, Batanghari District, and extracted with $70 \%$ ethanol. Doxorubicin ${ }^{\circledR} 10 \mathrm{mg} / 5 \mathrm{ml}$ in $\mathrm{NaCl} 0,9 \%$ was obtained from Novell Pharmaceutical Laboratories Bogor Indonesia. Ethanolic extract of Pinang Masak Jambi (EEPMJ) diluted by DMSO was used as a sample (DMSO 99,5\% pro GC, Sigma Aldrich Chemic gmBH, Steinheim, Germany).

\section{Study Design}

This research was an experimental study with post-test only group design. The variables consist of independent variables (the series concentration of doxorubicin and EEPMJ), dependent variables (the percentages of MCF7 viability and death cells, $\mathrm{IC}_{50}$ ), and control variables (culture conditions, cell amount in each treatment, growth media, and incubation time).

\section{Phytochemical Screening}

The phytochemical screening of extract of flavonoid test used $\mathrm{HCl}$ concentrated with $\mathrm{Mg}$ powder. The saponin was tested by adding water in the extract in reaction tubes.
Alkaloid tests used Dragendorf and Mayer reagents. The tannin test was performed by adding $\mathrm{FeCl}_{3}$ to filtrate extracts. Meanwhile, steroid and triterpenoid tests used Liebermann-Burchard.

\section{Cell Line Culture}

MCF-7 cells were cultivated in Dulbecco's Modified Eagle Media (DMEM) (Gibco), supplemented with 10\% (v/v) Fetal Bovine Serum (FBS) Qualified (Gibco, Invitrogen USA), 2\% (v/v) penicillin-streptomycin (Gibco, Invitrogen USA), and 0,5\% fungizone (Gibco, Invitrogen USA). Cells culture was incubated at temperature $37^{\circ} \mathrm{C}$ and $5 \% \mathrm{CO}_{2}$.

\section{Cytotoxicity Assay to the MCF-7}

\section{The preparation of RPMI 1640 culture medium}

The preparation of RPMI 1640 media used phosphate saline buffer (PBS) solution, trypsin solution, and trypan blue solution. MCF-7 cell density was calculated using a hemocytometer by mixing $20 \mu \mathrm{l}$ of cell suspension to $180 \mu 1$ of trypan blue at $100 x$ magnification.

\section{Preparation of MCF-7 cell suspension}

The inactive cell in the ampoule container was taken from the liquid nitrogen tank and immediately thawed at $37^{\circ}$ $\mathrm{C}$, then the ampoule was sprayed with $70 \%$ ethanol. The ampoule was opened and the cells were transferred into a sterile conical tube containing RPMI 1640 medium. The cell suspension was centrifuged at $3000 \mathrm{rpm}$ for 5 minutes, and then the supernatant was removed. A volume of $1 \mathrm{ml}$ of growing medium containing $10 \%$ FBS was added, and the cells were suspended until homogeneous. The cells were grown in several small tissue culture flasks (3-4 pieces), incubated in an incubator at $37^{\circ} \mathrm{C}$ with a flow of $5 \% \mathrm{CO}_{2}$. After 24 hours, the medium was replaced. The cells are grown until confluent and sufficient for the study.

\section{Preparation of the test solution}

The extraction results of Areca Fruit (A. catechu Linn.) were taken as much as $50 \mathrm{mg}$ to be dissolved with $0.25 \%$ DMSO so that the concentration of $625 \mu \mathrm{g} / \mathrm{ml}$ obtained. Further, the dilution with a concentration of 156.25 ; $78.12 ; 39.06 ; 19,53 ; 9.76$; and $4.88 \mu \mathrm{g} / \mathrm{ml}$ is made. Doxorubicin, which is used as a positive control, was made with a concentration of $3.0 ; 2.0 ; 1.0 ; 0.5$; and 0.25 $\mu \mathrm{g} / \mathrm{ml}$ of mother liquor $(500 \mu \mathrm{g} / \mathrm{ml})$.

\section{Single cytotoxicity test on MCF-7 cells}

The viable cell count for cytotoxicity test was carried out by dividing the groups into media plus MCF-7 cells as negative controls, MCF-7 cells plus Dimethyl Sulfoxide (DMSO) solvent as solvent control and MCF7 cells plus Doxorubicin as positive controls made in 5 concentrations, which are $3.0 ; 2.0 ; 1.0 ; 0.5$; and $0.25 \mu \mathrm{g} /$ 
$\mathrm{ml}$. Moreover, testing of EEPMJ groups was carried out with 6 concentrations $(156.25 ; 78.12 ; 39.06 ; 19,53 ; 9.76$; and $4.88 \mu \mathrm{g} / \mathrm{ml})$. Each concentration that has inserted into the 96 plates is as much as $100 \mu \mathrm{L}$ of RPMI 1640 media and then added MCF-7 cell suspension of $100 \mu \mathrm{l}$. The level series was repeated three times (triplications) to make it more valid. Then, the culture was incubated for 24 hours at $37^{\circ} \mathrm{C}$. The number of living MCF-7 cells (yellow) or dead (blue) cells was calculated by reacting $50 \mu 1$ of blue trypan with $50 \mu 1$ of cells for 3 minutes and used $10 \mu \mathrm{l}$ of the suspension to count the cells number. The percentage of cell death with the direct calculation method (viable cell count) was calculated using the formula used by Doyle and Griffith.

The cytotoxicity test of the doxorubicin and EEPMJ combination on MCF-7 cells

In the cytotoxic assay of the doxorubicin and EEPMJ combination, the determination of the series of concentrations of EEPMJ and doxorubicin referred to the $\mathrm{IC}_{50}$ value produced in a single cytotoxic test. These aim to provide an optimal synergistic effect. The concentration series used in the combination cytotoxic test was shown in Table 1.

Table 1. The series concentration of combination EEPMJ with doxorubicin

\begin{tabular}{llll}
\hline $\begin{array}{l}\text { Doxorubicin } \\
\left(\mathbf{I C}_{\mathbf{5 0}}\right)\end{array}$ & \multicolumn{3}{c}{ EEPMJ $\left(\mathbf{I C}_{\mathbf{5 0}}\right)$} \\
\cline { 2 - 4 } & $\mathbf{1 / 8}$ & $\mathbf{1 / 4}$ & $\mathbf{1 / 2}$ \\
\hline $\mathbf{1 / 8}$ & $1 / 8: 1 / 8$ & $1 / 8: 1 / 4$ & $1 / 8: 1 / 2$ \\
$\mathbf{1} / \mathbf{4}$ & $1 / 4: 1 / 8$ & $1 / 4: 1 / 4$ & $1 / 4: 1 / 2$ \\
$\mathbf{1} / \mathbf{2}$ & $1 / 2: 1 / 8$ & $1 / 2: 1 / 4$ & $1 / 2: 1 / 2$ \\
\hline
\end{tabular}

Cell viability assay measured by MTT [3,(4,5-dimethylthiazol-2-yl)-2,5-diphenyl tetrazolium bromide] for cytotoxicity test

MCF-7 cells as a breast cancer cell were grown in 96 well plates with $12 \times 10^{3}$ cells/well before exposed to drug treatment. For viability cells assay, cells were treated for $24 \mathrm{~h}$ with various dosages of EEPMJ its self and in combination with doxorubicin. Growth media (Dulbecco's Modified Eagle Media (DMEM) enrichment) added to the cells was used as a negative control (cell control), while the doxorubicin added to the cells as a positive control. The concentrations used for cytotoxic tests are $2.5,5,10,25,50,100$, and $150 \mu \mathrm{g} / \mathrm{ml}$. MTT solution $(0,5 \mathrm{mg} / \mathrm{ml}$ in PBS) was added to each well, and the cells were incubated for $3 \mathrm{~h}$ at $37^{\circ} \mathrm{C}$. Viable cells react with MTT to form purple formazan crystal. After 4 h, stopper 10\% (w/v) Sodium Dodecyl Sulphate $0,01 \mathrm{~N} \mathrm{HCl}$ was added to dissolve formazan crystal. Cells were incubated overnight and protected from light. The absorbance was determined by ELISA reader at $595 \mathrm{~nm}$. The absorbance of each well converted to the percentage of viable cells :

$\%$ Viable cells $=\frac{\text { Treated cells abs }- \text { Medium control abs }}{\text { Negative control (Cells control) abs }- \text { Medium control abs }} \times 100 \%$

\section{Analysis of Combination Index (CI)}

The potency of applications in combination therapy was analyzed using the combination index method (combinatorial index method / CI) (Chou, 2010). The CI value is used to determine the effect given by two compound combinations, whether synergistic, additive, or antagonistic effects.

\section{Statistical Analysis}

Statistical analysis was performed using analysis of variance (ANOVA) with Bonferroni'stest (SPSS release 16.0). Data were expressed as Mean $\pm \mathrm{SD}$.

\section{RESULTS AND DISCUSSION}

\section{Phytochemical screening of EEPMJ}

Based on phytochemical screening results, EEPMJ contains triterpenoid compounds, alkaloids, flavonoids, and saponins with positive results. The flavonoid fractions from pinang, which is proanthocyanidin estimated to have cytotoxic activity in the same ways related to the Leigh (2003) in grape seeds. So, it gives positive results from the crude extracts that have tested.

\section{Cytotoxic effects of EEPMJ and Doxorubicin using MTT assay}

Cytotoxic tests were carried out to determine the cytotoxic potential of EEPMJ and doxorubicin against MCF-7 cells with test parameters that could inhibit cell growth by up to $50 \%\left(\mathrm{IC}_{50}\right)$. According to Liu et al., 1996; Janicke et al., 1998; Srinivasula et al., 1996, the MCF-7 cell line was established from the breast cancer of a Caucasian woman, lack caspase-3 activity due to a point mutation in the gene coding for this protein. Therefore, the concentrations used for cytotoxic tests are $2.5,5,10,25,50,100$, and $150 \mu \mathrm{g} / \mathrm{ml}$. EEPMJ and single doxorubicin showed cytotoxic activity against MCF-7 cells, which increased with the amount of concentration. The treatment of EEPMJ showed good cytotoxic potential with $\mathrm{IC}_{50}$ values of $75.1 \mu \mathrm{g} / \mathrm{ml}$. It means that EEPMJ was able to inhibit MCF-7 cell growth by up to $50 \%$ by $75.1 \mu \mathrm{g} / \mathrm{ml}$. Based on Prayong et al. (2008), compounds with $\mathrm{IC}_{50}$ values below $100 \mu \mathrm{g} / \mathrm{ml}$ have potent cytotoxicity against cancer cells. Meanwhile, doxorubicin has a cytotoxic effect with $\mathrm{IC}_{50}$ values of $2 \mu \mathrm{g} / \mathrm{ml}$. Hence, the morphological changes in MCF7 cells cause a decrease in MCF-7 cell viability. Cell viability that occurs is the result of conversion from the activity of succinate dehydrogenase enzyme to reduce MTT reagent to formazan, which is comparable to cell viability. The increase in concentration causes a decrease in cell viability (dose-dependent phenomenon) (Figure 1). 

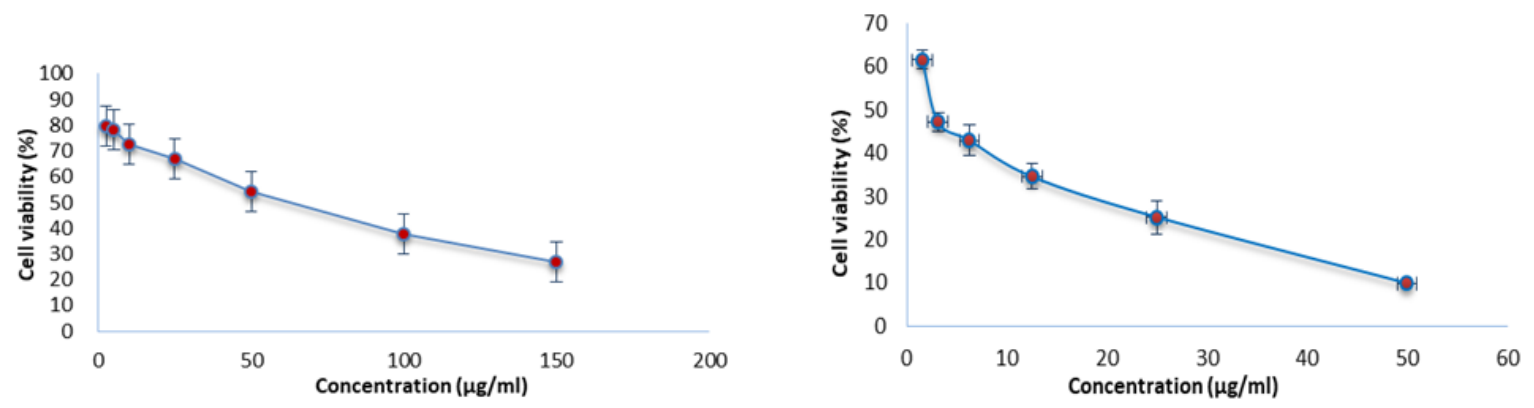

Figure 1. Cytotoxic effect EEPMJ (A) and Doxorubicin (B) on decreasing cell viability of MCF-7 using MTT assay. The assay performed by incubating 104 cells/well with EEPMJ $(2,5-150 \mu \mathrm{g} / \mathrm{ml})$ and doxorubicin $(1,5-50 \mu \mathrm{g} / \mathrm{ml})$ for $24 \mathrm{~h}$. After $24 \mathrm{~h}$, cells were added by MTT reagent to calculate the absorbance which represent viable cells.
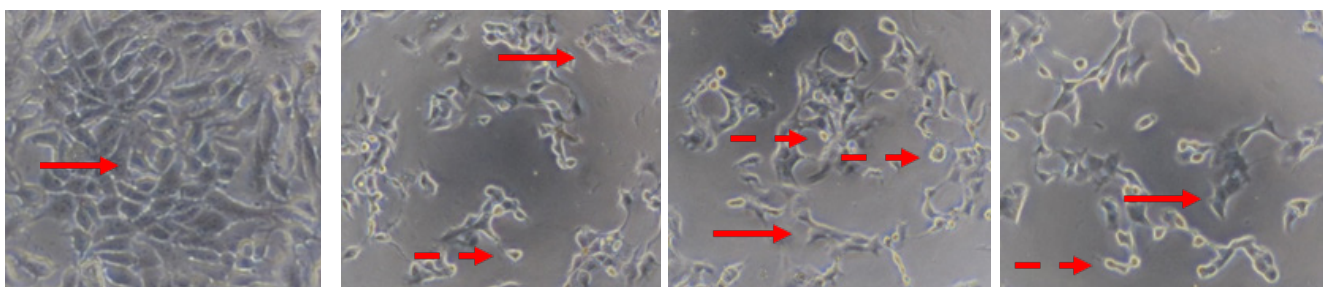

Figure 2. Cytotoxic effects of combination of EEPMJ with doxorubicin on morphological changes in MCF-7 cells using MTT assay. 12x103 cells were grown in 96-well plates and incubated 24 hours in high glucose DMEM media with various concentrations of combination solutions. (A) Morphological MCF-7 cell. Morphological changes in cells after the combination treatment of EEPMJ $37.5 \mu \mathrm{g} / \mathrm{ml}$ with doxorubicin, respectively; (B) concentration of $0.25 \mu \mathrm{g} /$ $\mathrm{ml}$; (C) $0.5 \mu \mathrm{g} / \mathrm{ml}$; and (D) $1 \mu \mathrm{g} / \mathrm{ml}$. MCF-7 cell morphology (arrow) and morphology of MCF7 cells (broken arrows). Observation under a microscope magnification 100x, bars: $50 \mu \mathrm{m}$.

Increased cytotoxic effects due to a combination of EEPMJ and doxorubicin are the expected results, as shown in Figure 2. The combination of both causes a decrease in dehydrogenase succinic enzymatic activity that correlates with cell viability. Its results in mutually reinforcing effects mean the higher concentration of EEPMJ used, the stronger the cytotoxic increase of doxorubicin by EEPMJ, as shown in Figure 2. Morphological observations of cells due to combination treatment showed that the treatment of EEPMJ enhanced the cytotoxic effect of doxorubicin treatment. According to Kwan et al. (2016), phenotypically, cell shrinkage, chromatin condensation, plasma, membrane blebbing, DNA fragmentation, and collapse of the cell into small fragments (apoptotic bodies) are the characteristics of apoptosis. The phase-contrast images showed the decrease of cell numbers and induced cell shrinkage and cell detachment from the monolayer surface compared with untreated cells. Apoptotic bodies, which appeared to be round or oval masses of cytoplasm, could be seen and shows an increase in the number of apoptotic cells corresponding to the length of incubation. In this case, we used EEPMJ as a sample.

Cell size due to combination treatment tends to be smaller than its self doxorubicin treatment (Figure 2). This phenomenon is quite interesting because the combination of the two compounds indicates the occurrence of molecular interactions was increasing in cytotoxic properties when compared with the single treatment of each compound. Combination of $0.25 \mu \mathrm{g}$ / $\mathrm{ml}, 0.5 \mu \mathrm{g} / \mathrm{ml}$, and $1 \mu \mathrm{g} / \mathrm{ml}$ of doxorubicin with EEPMJ $9.375 \mu \mathrm{g} / \mathrm{ml}, 18.75 \mu \mathrm{g} / \mathrm{ml}$ and $37.5 \mu \mathrm{g} / \mathrm{ml}$ showed higher effects of doxorubicin on MCF-7 (Figure 3). At the higher combination concentration of EEPMJ 9,375 $\mu \mathrm{g} / \mathrm{ml}$ with $0.25 \mu \mathrm{g} / \mathrm{ml}, 0.5 \mu \mathrm{g} / \mathrm{ml}$, and $1 \mu \mathrm{g} / \mathrm{ml}$ of doxorubicin, showed inhibition of proliferation up to $67,39 \%$ on MCF-7 cells. This result suggested that this combination gives an improvement of the doxorubicin cytotoxic effect.

In addition, cytotoxic interaction between EEPMJ and doxorubicin explained by the observation of synergistic or additive effects. Based CI (Combination Indeks) calculating by Chou-Talalay equation showed a strong synergistic effect of combination EEPMJ and doxorubicin $(\mathrm{CI}<1)$ (Table 1). This result suggested that the combination of EEPMJ and doxorubicin resulted in synergistic anticancer activity. Almost all of the combination treatments of EEPMJ and doxorubicin gave strong synergistic and synergistic results (CI 0.1-0.7), which means the effect of the combination of the two test compounds was higher than the sum of the effect of every single treatment. These indicate that the administration of 
Table 2. Combination Index (CI) value for treatment combination of EEPMJ and Doxorubicin on MCF-7 cells

\begin{tabular}{llll}
\hline \multirow{2}{*}{ EEPMJ Concentration $(\boldsymbol{\mu g} / \mathbf{m l})$} & \multicolumn{3}{c}{ Doxorubicin Concentration $(\boldsymbol{\mu g} / \mathbf{m l})$} \\
\cline { 2 - 4 } & 0,25 & 0,5 & 1 \\
\hline 9.375 & 0.18 & 0.23 & 0.29 \\
18.75 & 0.36 & 0.42 & 0.91 \\
37.5 & 0.80 & 1.00 & 3.12 \\
\hline
\end{tabular}

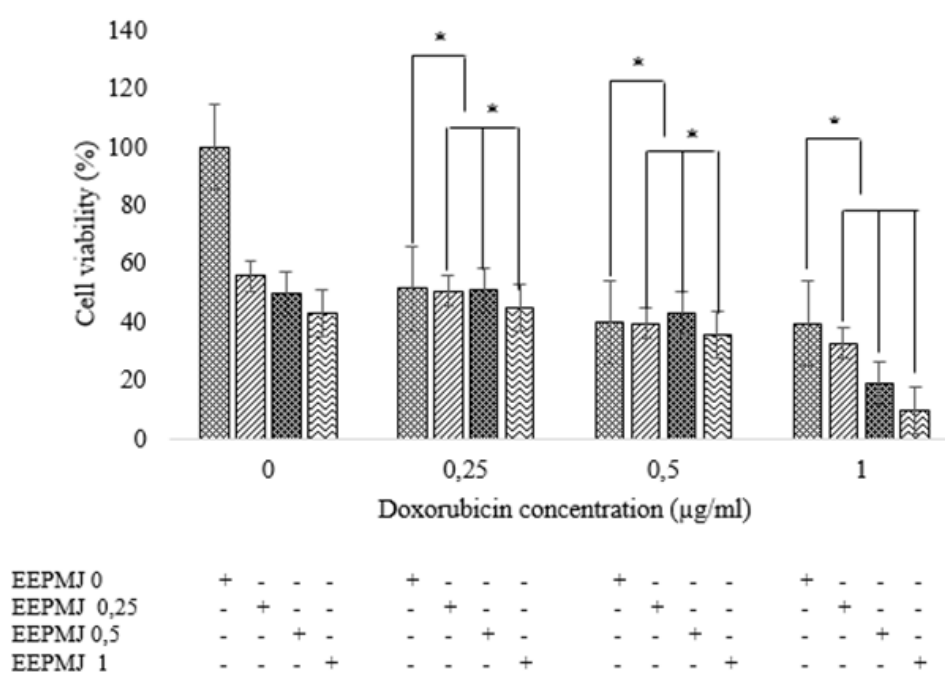

Figure 3. Combination effect of EEPMJ and doxorubicin to the proliferation of MCF7 using MTT assay. The assay performed by incubating 104 cells/well with EEPMJ (1/2, $1 / 4,1 / 8$ IC50) and doxorubicin (1/2, 1/4, 1/8 IC50) for $24 \mathrm{~h}$. After $24 \mathrm{~h}$, cells were added by MTT reagent to calculate the absorbance which represent viable cells. Statistical analysis is performed using analysis of variance (ANOVA) with Bonferroni'stest (SPSS release 16.0). Data were expressed as (Mean $\pm \mathrm{SD})$. *combination was considered significant to doxorubicin single treatment $(\mathrm{p}<0,05)$.

EEPMJ at low concentrations can increase the cytotoxic activity of doxorubicin in MCF-7 cells.

\section{CONCLUSION}

The results of this study indicate that the combination of EEPMJ and doxorubicin provides various effects ranging from synergistic to antagonistic. This synergistic effect occurs because EEPMJ can increase the cytotoxicity of doxorubicin.

\section{ACKNOWLEDGMENT}

This study was supported in part Grant from PNBP Faculty of Science and Technology, Universitas Jambi, Jambi, Indonesia.

\section{REFERENCES}

American Cancer Society. (2018). Cancer Facts \& Figures 2018, US, American Cancer Society.
The Jakarta Breast Cancer Foundation Dharmais Hospital. Chou, T. C. (2010). Drug Combination studies and their synergy quantification using the Chou-Talalay method. Cancer Research, 70(2), 440-447.

El-Sayyad, H. I., Ismail, M. F., Shalaby, F. M., Abou-ElMagd, R. F., Gaur, R. L., Fernando A., Raj, M. H. G., \& Ouhtit, A. (2009). Histopathological effects of cisplatin, doxorubicin and 5-flurouracil (5-FU) on the liver of male albino rats. International Journal of Biological Sciences, 5(5), 466-473.

Ferguson, P.J., Kurowska, E., Freeman, D.J., \& Koropatnick, D.J. (2004). A flavonoid fraction from cranberry extract inhibits proliferation of human tumor cell lines, Journal of Nutrition, 134, 1529-1535.

Globocan. (2012). Estimated cancer incidence, mortality and prevalence worldwide in 2012. France: WHO.

Han, X., Pan, J., Ren, D., Cheng, Y., Fan, P., \& Lou, 
H. (2008). Naringenin-7-O-Glucoside Protects Againts Doxorubicin-Induced Toxicity In H9c2 Cardiomyocytes by Induction of Endogenous Antioxidant Enzymes. Food and Chemical Toxicology, 46 (9), 3140-3146.

InfoDATIN. (2016). Months of caring breast cancer. Jakarta: Ministry of Health Indonesian, The Center of Data and Communication.

Kwan, Y. P., Saito, S. T.., Ibrahim, D., Al-Hassan, F. M. S.,., Oon, C. E.., Chen, Y., Jothy, S. L.., Kanwar, J. R., \& Sasidharan, S. (2016). Evaluation of the cytotoxicity, cell-cycle arrest, and apoptotic induction by Euphorbia hirta in MCF-7 breast cancer cells. Pharmaceutical Biology, 54(7), 1223-1236.

Lee, E. L., \& Westcarth, L. (2012). Neurotoxicity associated with cancer therapy. Journal of Advanced Practitioner in Oncology, 3(1), 11-21.

Leigh, M.J. (2003). Health benefits of grape seed proanthocyanidin extract (GSPE). Nutrition Noteworthy, $6(1)$, article 5.

Li, F., Zhou, X., Zhou, H., Jia, J., Li, L., Zhai, S., \& Yan, B. (2016). Reducing both Pgp overexpression and drug efflux with anti-cancer gold-paclitaxel nanoconjugates. PLoS One, 11(7), 1-16.
Poddar, S., Sultanal, R., Sultana, R., Mohammad, M., Azad, M. A. K., \& Hasnat, A. (2009). Pattern of adverse drug reactions due to cancer chemotherapy in tertiary care teaching hospital in Bangladesh. Dhaka University Journal of Pharmaceutical Sciences, 8(1), 11-16.

Ramadori, G., \& Cameron, S. (2010). Effects of systemic chemotherapy on the liver. Annals of Hepatology, 9(2), 133-143.

Sari, L.M., Subita, G.P., El Auerkari. (2017). Potential antioxidant and cytotoxic activities of areca nut (Areca catechu Linn.) extract in human oral squamous cell carcinoma and keratinocyte cells. Asian Journal of Pharmaceutical and Clinical Research, 10 (10), 286291.

Setiawati A., Susidarti R.A., \& Meiyanto, E. (2011). The increase of cytotoxic effects of doxorubicin by hesperidin to the T47D cell. Bionatura - Jurnal Ilmu - Ilmu Hayati dan Fisik, 13(2), 85-92.

Smeltzer \& Bare. (2002). Keperawatan Medikal Bedah. Ed. 8 Vol. 1, Jakarta: EGC.

The Jakarta Breast Cancer Foundation Dharmais Hospital. (2009). Retrieved from 